Barna Boglárka ${ }^{1}$

\title{
A harci stressz kezelésének alternatívái a modern fegyveres küzdelmek fényében
}

\section{Psychological Methods of the Treatment of Combat Stress Based on Modern Armed Struggles}

\begin{abstract}
Absztrakt
A háború emberre gyakorolt hatásáról már az ókori források is említést tesznek, kiemelve azokat a szempontokat, amelyek mentén a győzelem vagy éppen a veszteség könnyebben bejósolhatóvá válhat. Az egyik, ókortól napjainkig átívelö szempont a félelem és a félelemböl fakadó tettek megismerése. Bár a fegyveres küzdelmekhez köthetö félelem jelenségével minden korban találkozhatunk, a harci stressz fogalmának meghatározása, a stresszreakciók és a kezelésükre irányuló kutatások a 20. századig várattak magukra. A következőkben áttekintem azokat a föbb történelmi példákat, amelyek a 19. század második felétöl kulcsszerepet játszottak a harcistressz-kutatások kialakulásában és fejlödésében. A példákon keresztül a harci stressz megitélésének változása és kezelésére tett kísérletek is bemutatásra kerülnek. A jelenség hatását idő szerinti lebontásban tekintem át, kitérve az ASR, ASD és PTSD közti föbb különbségekre. Ismertetem továbbá azokat a terápiás módszereket, amelyek a harci stressz különböző fajtáinak kezelésénél eredményesek lehetnek. A jelenség kezelésének különböző módjai és egyes elemei sikerének értékelésével képet kaphatunk a harci stressz komplexitásáról és azokról a tényezökröl, amelyek a vizsgálatában jelentös szereppel bírnak.
\end{abstract}

Kulcsszavak: harci stressz, stresszkezelés, ASR, ASD, PTSD

Nemzeti Közszolgálati Egyetem, Hadtudományi Doktori Iskola doktorandusz, National University of Public Service, Doctoral School of Military Science, PhD student, e-mail: barna.boglarka@uni-nke.hu, ORCID: https://orcid.org/00000001-7839-0086 


\begin{abstract}
The influence of war on men has been already noticed in ancient times. Ancient sources describe some aspects of war which can be the key of victory. One of them emphasises that knowing the human aspect of war, including the emotional reactions on combat like fear, makes the outcome of war more predictable. Although the phenomenon of fear associated with armed struggles can be encountered at all era, defining the concept of combat stress, stress responses, and research into treatment have been awaited until the $20^{\text {th }}$ century. In the following, some main historical examples will be reviewed that have played a key role in the development of combat stress research since the second half of the $19^{\text {th }}$ century. Through the examples, changes in the assessment and treatment of combat stress are also presented. The effects of this phenomenon are reviewed, suggesting a separation between ASR, ASD and PTSD. Connecting to the three mentioned group of combat stress reactions, the main differences in the treatment are also introduced.
\end{abstract}

Keywords: combat stress, psychological treatment methods, ASR, ASD, PTSD

\title{
A háború emberre gyakorolt hatásának felismerése és a harci stressz
}

A harci stressz napjainkban is használt fogalma megközelítőleg a 20. század első felében, az első világháború idején alakult ki, ${ }^{2}$ azonban már a háborúról szóló legkorábbi írásos emlékek is tartalmaznak utalásokat a háború emberekre gyakorolt hatásáról (lásd például: Szun-ce, ${ }^{3}$ Xenophón, ${ }^{4}$ Vegetius, ${ }^{5}$ Zrínyi Miklós, ${ }^{6}$ Carl von Clausewitz ${ }^{7}$ ). A legtöbb olyan forrás azonban, ami már tartalmazza azokat a kihívásokat, amelyekkel a katonák a harctéren szembesülnek, a 19-20. századtól maradt fenn. ${ }^{8}$ Marlowe (2001) munkájában a harci stressz pszichológiai és pszichoszociális kockázatait ismerteti, példaként említve az amerikai polgárháborút. Az 1861-1865 közti időszakban a harci stressz hatására a dezertálás jelensége mind az északi, mind a déli seregben megszokott volt. Emellett a források több olyan esetről számolnak be, ahol az ütközet közepén a katonák a magas fokú stressz hatására pánikrohamot kaptak. ${ }^{9} \mathrm{~A}$ harci stressz különféle megnyilvánulásai mellett a források kitérnek a jelenség utóhatásának - a nosztalgiának

\footnotetext{
Franklin D. Jones: Psychiatric Lessons of War, in: F. D. Jones et al. (eds.), War Psychiatry, TMM Publications, Washington, D. C., 1995, 1-33.

Szun-ce: A hadviselés törvényei, http://mek.oszk.hu/01300/01345/01345.htm (Letöltve: 2019. 02. 25.)

Xenophón: Kürosz nevelkedése/Anabázis, Bibliotheca Classica sorozat, Európa Könyvkiadó, Budapest, 1979.

Vegetius, Renatus Publius Flavius: Epitoma rei militaris, Várady László (ford.): A hadtudomány foglalata, in: Hahn István (szerk.), A hadművészet ókori klasszikusai, Zrínyi Katonai Kiadó, Budapest, 1963, 751-865.

Zrínyi Miklós: Vitéz hadnagy, (1650-1653), http://mek.oszk.hu/01100/01137/01137.htm\#11 (Letöltve: 2019. 02. 25.)

Clausewitz, Carl von: A háborúról, Athenaeum, Budapest, 1917. http://mek.oszk.hu/13200/13240/pdf/13240_1.pdf (Letöltve: 2019. 01. 16.)

8 Russel W. Glenn - Todd C. Helmus: A Look Back: A Brief History of Combat Psychiatry, in: Russel W. Glenn - Todd C. Helmus (eds.), Steeling the Mind, RAND Corporation, Santa Monica, 2005, 9-22.

9 David H. Marlowe: Psychological and Psychosocial Consequences of Combat and Deployment with Special Emphasis on the Gulf War, RAND Corporation, Santa Monica, 2001.
} 
és a "soldier's heart" (napjainkban: posttraumatic stress disorder, a továbbiakban: PTSD) - leírására is. A nosztalgiát mint betegséget először egy svájci orvos jegyezte le 1678-ban, aki a jelenséget a honvágy, nagyfokú agresszió és fegyelmi problémák megjelenésével, továbbá a társaktól való elidegenedéssel, szorongással és bizalmatlansággal jellemezte. ${ }^{10}$ Ezek a tünetek azonban Marlowe szerint a felkészülés közben eltűnnek. A "soldier's heart" a nosztalgiával szemben egyfajta szívelégtelenség, ami megnövekedett pulzusszámmal és fáradtsággal jár, annak ellenére, hogy a személy orvosi vizsgálatok alapján egészségesnek mondható. Míg a nosztalgiát jellemzően az amerikai polgárháborús harci stressz utóhatásaként azonosították, a "soldier's heart" jelenségét a második búr háború és az első világháború időszakában jegyezték le.."

Az első világháború mozgó háború szakaszában (1914-1915) a "soldier's heart", mint a harci stressz utóhatása mellett több, a hadszíntéri eseményekre adott akut pszichés reakciót figyeltek meg, azonban ezek a reakciók nem mutattak jelentős eltérést a korábbiaktól. Ezzel szemben az állóháború kialakulásával tömegével jelentek meg olyan tünetek, mint bénulás, vakság, amnézia, amiket sok esetben fejfájás, aluszékonyság, depresszió és magas fokú szorongás kísért. ${ }^{12}$ Kezdetben a brit megközelítés a jelenséggel kapcsolatban a félelmet azonosította, mint háttértényező, mivel általánosságban úgy vélték, hogy leginkább a nők hajlamosak pszichés rendellenességre. ${ }^{13}$ A későbbiekben „shell shock-nak” nevezett jelenség vizsgálata során világossá vált, hogy a háború katonákra gyakorolt hatása nem merül ki a félelemben és magas fokú szorongásban. Továbbá a kutatások rámutattak, hogy mind a harci stressz, mind az utóhatása kezelést igényel. ${ }^{14}$

Az első világháború tapasztalatait felhasználva, az Amerikai Egyesült Államokban már a következő nagy háborúra (második világháború) való felkészülésnél figyelembe vették a mentális sérülések lehetőségét. A toborzás során több mint 1,5 millió jelöltet utasítottak el, pszichés alkalmatlanságra hivatkozva. Személyiségtesztek és alkalmasságvizsgálatok segítségével próbálták minimálisra csökkenteni a veszteség kockázatát. Így azokat a személyeket, akik nem rendelkeztek megfelelő végzettséggel, a vizsgálat során magasabb fokú szorongást vagy erősebb neurotikus viselkedésjegyeket mutattak, elutasították. ${ }^{15}$ Ennek ellenére a háború során pszichés károsodást szenvedők száma a korábbiakhoz képest is jóval magasabb arányokat mutatott. ${ }^{16}$

Jones (1995a): i. m.

11 Edgar Jones et al.: Post-Combat Syndromes from the Boer War to the Gulf War: A Cluster Analysis of Their Nature and Attribution, British Medical Journal, 324 (2002/7334) 397.

12 Franklin D. Jones: Traditional Warfare Combat Stress Casualties, in: Franklin D. Jones et al. (eds.), War Psychiatry, TMM Publications, Washington, D.C., 1995, 35-61.

13 Ben Shephard: Shell-Shock on the Somme, RUSI Journal, 141 (1996/3) 51-56.

14 Glenn-Helmus (2005): i. m.

Jones (1995b): i. m.

16 Ben Shephard: A War Of Nerves: Soldiers and Psychiatrists, 1914-1994, Pimlico, London, 2002. 


\section{A harci stressz kezelési módjai - történeti áttekintés}

\section{A kezelésre tett kísérletek az első és második világháború alatt}

A „shell shock" jellegzetes tünetegyüttese felhívta mind a katonai vezetők, mind az egészségügyi személyzet és a társadalom egészének figyelmét a harc során szerzett mentális problémák kezelésére. Az 1900-as évek elején a férfi nem felé irányuló attitüdök és elvárások, miszerint a gyengeség, félelem vagy (negatív) érzelmek kimutatása nem férnek össze az „igazi férfi” viselkedéséről alkotott képével, a probléma kezelését is nagymértékben befolyásolta. Kezdetben azok a férfiak, akik képtelenek voltak önállóan megküzdeni a harci stresszel, tudattalanul is olyan viselkedésjegyeket kezdtek közvetíteni környezetük felé, amelyek mások számára (bajtársak, katonai vezetők) is világossá tették helyzetüket. Sok esetben előfordult ugyanis, hogy azokat a katonákat, akik mindössze pszichés tüneteket mutattak fegyelmi eljárás alá vonták, több esetben pedig ki is végezték őket. ${ }^{17}$ A tömeghadseregek és az ipari forradalom hatására megjelenő egyre nagyobb pusztítást okozó fegyverek hatására azonban megnövekedett azoknak a katonáknak a száma, akik képtelenné váltak a harci stresszel való megküzdésre. Ennek eredményeként megszülettek az első kezelési módok. Kezdetben a brit katonák közül az érintetteket evakuálták és a hátországba szállították. A várt hatással ellentétben azonban a fizikai távolság tovább rontott a kliensek állapotán. A kiváltó ok kezelése hiányában a katonák többségénél a mentális sérülés élethosszig tartó pszichés problémákat eredményezett. ${ }^{18}$

A kezdeti sikertelenségek hatására Myers a front közelében hozott létre elkülönített központokat a háborús neurózis kezelésére. A katonák élelmet és egészségügyi ellátást kaptak a központokban, valamint a pszichoterápiát mint módszert elkezdték alkalmazni a mentális sérülések kezelésére. ${ }^{19}$ 1917-ben az amerikai Thomas William Salmon ellátogatott a Myers-féle központokba és javaslatot tett a kezelés hatékonyabbá tételére. Salmon úgy vélte, hogy a pszichés tünetegyüttes megjelenését követően a lehető legrövidebb időn belül szükséges kezelni a sérültet, lehetőleg a fronthoz közel eső helyen, azt az elvárást támasztva a katona felé, hogy hamarosan vissza kell térnie csapatához. Kenneth L. Artiss (1963) a módszert PIE-nak (proximity, immediacy, and expectancy) nevezte, ami később bővült a fiziológiás szükségletek kielégítésével (a továbbiakban: PIES: proximity, immediacy, expectancy, simplicity). ${ }^{20} \mathrm{~A}$ javaslat hatására a fronthoz közelebb eső, kezelésre alkalmas pontokat hoztak létre, ahol először látták el a sérültet. Azokban az esetekben, amikor a javulás pár napon belül nem következett be, az érintett személyeket továbbszállították kórházakba, ahol pszichiátriai felügyelet alá helyezték őket. ${ }^{21} \mathrm{~A}$ PIE-módszer látszólag sikeresnek bizonyult.

\footnotetext{
Shephard (2002): i. m.

Glenn-Helmus (2005): i. m.

Edgar Jones - Simon Wessely: Psychiatric battle casualties: an intra- and interwar comparison, British Journal of Psychiatry, 178 (2001/3) 242-247.

20 Kenneth L. Artiss: Human Behaviour Under Stress: From Combat to Social Psychiatry, Military Medicine, 128 (1963/10) 1011-1015.

21 Glenn-Helmus (2005): i. m.
} 
Az azonnali kezelés és a visszatérést szorgalmazó elvárás hatására mintegy $80 \%$-a a katonáknak visszatért csapatához. ${ }^{22} \mathrm{~A}$ második világháború során a harci stressz kezelésére a korábbi eljárást módosították, azonban valós sikereket nem értek el sem a harci stressz, sem pedig a PTSD kezelésében.

\section{A harci stressz kezelése a vietnámi háborúban}

Az első olyan 20. századi fegyveres konfliktus, ahol a mentális sérülést szerző katonák száma csökkenni látszott a vietnámi háború időszakára tehető. A látszólagos javulás lehetséges magyarázata azonban nem a harci stressz csökkentésére kifejlesztett hatékonyabb módszerekben keresendő. Részben köszönhető a 6-12 hónapos rotációs tervnek, valamint a lehetőségnek, miszerint a terepen harcoló katonák visszatérhettek bázisaikra. Továbbá ez esetben az amerikai katonák kevésbé kerültek kiszolgáltatott helyzetbe, például a sebesült katonákat már helikopterrel szállították biztonságos pontokra, megnövelve ezzel menekülési és túlélési esélyeiket. ${ }^{23} \mathrm{~A}$ harci stresszel való megküzdés tekintetében tehát jelentős tényezőnek bizonyult, hogy a korábbi elvárásokkal ellentétben a katonáknak megadták a lehetőséget a hazatérésre (a rotációs programnak köszönhetően már nem csak sérülés esetén térhettek haza), ami növelte a reményt és a morált. Az egyéni rotáció során azonban az egységek tagjai folyamatosan változtak, megnehezítve ezzel a csoportkohézió kialakulását. Emellett megjelent az úgynevezett „short-timer's szindróma” is, amely megnövelte mind a fizikai, mind a pszichés sérülések lehetőségét. Azoknál a katonáknál ugyanis, akiknek hazatérési napja közeledett, legtöbb esetben csökkent a morál és a harci kedv, veszélyeztetve ezzel nemcsak saját hazatérésüket, de társaik életét is. ${ }^{24} \mathrm{~A}$ short-timer's szindróma mellett szükséges kitérni a háború lezáró szakaszát jellemző megnövekedett drogfogyasztási arányra, valamint a visszaélések számának emelkedésére is. 1971-ig az Amerikai Egyesült Államok nem engedélyezte ugyanis sem anyaghasználat, sem pedig harci stressz hatására kialakult kontraproduktív viselkedésmintázat esetén a katonai szolgálatot teljesítők kivonását a hadszíntérről. Ennek változása azonban ugrásszerűen növelte a harci stressz viselkedéses megnyilvánulásainak számát, felhívva ezzel a katonai és állami vezetők figyelmét a jelenség megjelenésének egy újabb formájára. ${ }^{25}$ Összességében tehát, - bár kezdetben a mentális sérülések aránya az első és második világháborúhoz képest csökkenni látszott -, a vietnámi háború példázza, hogy a harci stressz kezelése nem merülhet ki rotációs programokban és az élet elvesztése ellen tett intézkedésekben (lásd: helikopterek használata). Rendszeres pszichológusi vizsgálat (és felülvizsgálat), valamint prevenció hiányában a harci stressz tünetei mindössze látszólag csökkenthetők. A stresszreakció ugyanis a stresszhatást követően akár hónapokkal később is jelentkezhet PTSD formájában.

\footnotetext{
Anthony Babington: Shell-Shock: A History of the Changing Attitudes to War Neurosis, Leo Cooper, London, 1997. Glenn-Helmus (2005): i. m.

Marlowe (2001): i. m.

25 Jack McCallum: Medicine, Military, in: Spencer C. Tucker (ed.), Encyclopedia of the Vietnam War: A Political, Social and Military History, ABC-CLIO, Santa Barbara, 1998, 423-428.
} 


\section{Változás az 1970-es, 1980-as években}

Valódi fordulat a harci stressz és a PTSD kezelésében az arab-izraeli háborúk idejére tehető, különös tekintettel a jom kippuri háborúra és az ötödik arab-izraeli háborúra. A vietnámi háborúhoz hasonlóan a jom kippuri háborúban is magas volt az aránya a mentális sérülést szenvedőknek. Bár Izrael az 1970-es években még nem rendelkezett a sérültek kezelésére megfelelő és múködőképes eljárással, alig 10 éven belül, az ötödik arab-izraeli háború idejére amerikai mintára kidolgozták. İgy az 1980-as évekre, a harci stressz hatására sérülést szenvedett katonák jelentős részét sikeresen kezelték. ${ }^{26}$ Noy és szerzőtársai viszont felhívják a figyelmet arra, hogy ez esetben is a mentális sérülések megközelítöleg 40\%-a a harci stresszt követő 1 éven belül jelentkezett. ${ }^{27}$

Stokes 1985-ben a korábbi tapasztalatok hatására a harci stressz szakemberek általi szabályozását és kezelését javasolta. Felismerte, hogy a kiválasztásnál végzett alkalmasságvizsgálatok, a rotációs program és a technikai vívmányok kiaknázása mellett szükséges a harci stressz kezelésére önálló orvosi egységeket létrehozni. ${ }^{28}$ Ennek köszönhetően az amerikai haderőnél megalakultak azok a csoportok, amelyek feladatai közé tartozik a csapatkohézió kialakítása, a harc pszichológiai aspektusaira való felkészítés, valamint a harci stressz kezelése. ${ }^{29}$

\section{A harci stressz kezelése napjainkban}

A 20. század fegyveres konfliktusai rávilágítottak arra, hogy a harci stressz jelensége összetett, így nem lehet mindössze szabadságok kiadásával és orvosi beavatkozásokkal kezelni. A jelenség hatásának csökkentésére már a stresszor megjelenése előtt preventív lépésekre van szükség. A prevenció ez esetben tartalmazhatja a megelőzést és az azonnali kezelést. A megelőzés a stresszor személyre gyakorolt hatásának intenzitását kívánja csökkenteni. ${ }^{30}$ Ennek egyik lehetséges módja a pszichológiai mérőeszközök megfelelő alkalmazása a kiválasztás során, valamint az új belépők rendszeres pszichológiai ellenőrzése, támogatása. Továbbá a megelőzés eszköztárába sorolható a felkészítés folyamata is. Ez tartalmazza mind a szakmai (például új technikai eszközök megismerése és használata), mind pedig a pszichológiai (például az ismeretlenség okozta szorongás csökkentése) felkészitést. A preventív lépések közé sorolható továbbá a tünetek jellegének felismerése és kezelése is. A stresszreakciók időbeli aspektusának ismerete hozzásegíti a szakembereket a kezelés sikeressége érdekében célravezető eszközök, terápiás módszerek kiválasztásához. ${ }^{31} \mathrm{~A}$ harci stressz hatásaként

26 Zahava Solomon - Rami Benbenishty: The Role of Proximity, Immediacy, and Expectancy in Frontline Treatment of Combat Stress Reaction Among Israelis in the Lebanon War, American Journal of Psychiatry, 143 (1986/5) 613-617.

27 Shabtai Noy - R. Levy - Zahava Solomon: Mental Health Care in the Lebanon War, 1982, Israel Journal of Medical Sciences, 20 (1984/4) 360-363.

28 Glenn-Helmus (2005): i. m.

29 Major Michael E. Doyle: Combat Stress Control Detachment: A Commander's Tool, Military Review, (2000/3) 65-71.

30 Barna Boglárka: A munkahelyi stressz idői vetülete és föbb forrásai a hadseregben, Hadtudományi Szemle, 11 (2018/1) 124-141.

31 Völgyi Zoltán: A harctevékenységekhez kapcsolódó stressz pszichológiai aspektusai, Hadtudományi Szemle, 11 (2018/1) 270-286. 
a stresszreakciók három, időben jól elkülöníthető csoportra bonthatók. Az ASR (acute stress reaction, a továbbiakban: ASR) egyfajta azonnali válasznak tekinthető, amikor a traumát követően a tünetek 2-3 napon belül jelentkeznek a legerösebben. Az ASD (acute stress disorder, a továbbiakban: ASD) hosszabb időintervallumot ölel fel, ami a stresszhatás utáni megközelítőleg 3-4 naptól egészen a 4-5 hétig tartó periódus. A harmadik csoportja a stresszreakcióknak a PTSD (posttraumatic stress disorder), ami időben a legelhúzódóbb stresszválasz. ${ }^{32}$ A fentiekben bemutatott példák az ASR és ASD kezelésének lehetséges módjait tartalmazzák. Ezek alapján tehát megelőzésnek nevezhetjük a fegyveres erők kiválasztása során alkalmazott pszichés alkalmasság mérését, a vietnámi háború során alkalmazott rotációs programot és a személyes biztonság növelésére tett kísérleteket, valamint a morál növelését. A tüneti kezelések csoportjába sorolhatjuk a PIES-módszert, a pszichoterápia alkalmazását, a pszichiátriai vizsgálatokat és felügyeletet. Az interperszonális kapcsolatok mind a megelőzésben, mind pedig a tüneti kezelésben fontos szerepet kapnak. A megelözés tekintetében a csoportkohézió kialakítása és a társas kapcsolatok mélyítése elengedhetetlen. Matz és munkatársai (2013) a munkahelyi elégedettség és munkahelyi stressz jelenségének vizsgálata során azt találták, hogy a munkatársak befolyásoló ereje a munkáról való vélekedés, a mindennapi munkaszituációk megélése és értékelése szempontjából kulcstényező. A munkatársak hatására tehát változhatnak gondolataink a munkáról és érzéseink a munkával kapcsolatban. Matz és munkatársai szerint a társas kapcsolatok jelentősebb befolyásoló tényezők mint a személyiséghez füződő faktorok, így tehát nagyobb mértékben befolyásolják az attitüdöket és a viselkedést. ${ }^{33}$ A harci stressz megelőzése és kezelése szempontjából Matz és munkatársai vizsgálata kimondja, hogy a csoport, mint védőfaktor müködik, így felhasználható mind a stresszor megjelenése előtt, mind a kezelés szakaszában.

Amennyiben a tünetek rövid távon nem jelentkeznek, vagy a kezelés elmarad, a PTSD kialakulásának kockázata jelentősen megnövekszik. A PTSD kezelése lényegében eltér az ASR és az ASD kezelésétől, hiszen ez esetben a harci stressz okozta válaszreakció már térben és időben is távol esik a stresszortól. Fontos megemlíteni azonban, hogy hasonlóan az ASR-hez és ASD-hez, a PTSD kezelésében is nagy szerepet játszanak a társas kapcsolatok, a személy preferenciájának megfelelő pszichoterápiás kezelés alkalmazása és az utánkövetés. Emellett a PTSD kezelésének sikerességét nagymértékben befolyásolja az adott fegyveres konfliktus társadalmi megítélése is. ${ }^{34}$ Dolgozatom további részében a terápiás lehetőségeket a jelenség időbeli lebontásában vizsgálom, sorra véve az ASR, ASD és PTSD esetében hatékonynak bizonyuló és széles körben alkalmazható kezelési módszereket.

32 Deborah Kaminer - Gillian Eagle: Trauma interventions for individuals, groups and communities, in: D. Kaminer, G. Eagle (eds.), Traumatic Stress in South Africa, Wits University Press, 2010.

33 Adam K. Matz et al.: Predictors of turnover intention among staff in juvenile correctional facilities: The relevance of job satisfaction and organizational commitment, Youth Violence and Juvenile Justice, 11 (2013/2) 115-131.

34 Sarah E. Ullman - Henrietta H. Filipas: Predictors of PTSD Symptom Severity and Social Reactions in Sexual Assault Victims, Journal of Traumatic Stress, 14 (2001/2) 369-389. 


\section{A harci stressz kezelésének módjai}

A harci stressz kezelése egy komplex folyamat, ami magába foglalja egyrészt a pszichoterápiát és a közösségen alapuló módszereket, másrészt a pszichiátriai és gyógyszeres kezeléseket. A jelenség vizsgálata során a pszichoterapeuták leginkább a traumatikus események által kiváltott tünetegyüttes leírására és kezelésére helyezték a hangsúlyt, alapul véve Freud korai munkásságát. A szemléletmód változásának és megújulásának kezdete megközelítőleg az 1980-as évek második felére tehető, amikor az ötödik arab-izraeli háború hatására megkezdődött az újabb kutatási eredmények gyakorlatba ültetése. Az elmúlt megközelítőleg 30 évben a harci stressz kezelésére számos elmélet született, amelyeket tartalmuk szerint csoportosíthatunk. A hagyományos beszédalapú terápiák mellett megjelentek a testorientált módszerek és a kisebb csoportokon vagy nagyobb közösségen alapuló eljárások is. ${ }^{35} \mathrm{~A}$ továbbiakban a harci stressz időbeli vetülete mentén az egyéni és csoportos módszereket mutatjuk be.

\section{A harci stressz kezelésének alapkövetelményei}

Judith Herman a traumatikus stressz kezelése kapcsán három fő, egymásra épülő szempontot emel ki. A kezelés sikerességéhez szükséges a személyes biztonság érzetének megteremtése, a trauma feldolgozása és integrálása, valamint a társas támasz. ${ }^{36}$ Azokban az esetekben, amikor a terápia során a személy nem érzi biztonságban magát, nem tud elmélyedni a folyamatban, magasfokú szorongás lép fel. A szorongás nem csupán meggátolja a harci stressz okozta trauma feldolgozását, hanem sok esetben súlyosbítja a traumatikus stressz egyénre gyakorolt hatását. Herman alapkritériumai szerint tehát minden terápiás módszer sikerének legalapvetőbb eleme a személy biztonságérzetének megteremtése, támogatása. Amennyiben a biztonság feltétele teljesül, megkezdődik a trauma feldolgozása. A feldolgozás során a traumatikus stressz és a beavatkozás közt eltelt idő döntő jelentőséggel bír. A fentiekben már ismertetett azonnali és szakszerủ beavatkozás (PIES) hiánya növeli a hosszú távú mentális rendellenességek kialakulását. A traumatikus esemény és a terápia megkezdése közt eltelt ideális időtartam megállapítása azonban nehézségekbe ütközik. Újabb megfigyelések alapján ugyanis az események feldolgozását elősegíti, ha a terápia megkezdésekor a személy már képes legalább részben objektívan értékelni az átélt eseményeket. ${ }^{37}$ Kaminer és Eagle szerzőpáros a Herman-féle szempontok mellett kiemeli az egyéni döntéshozatal szerepét is. Az ugyanis, hogy a személy saját döntése alapján vagy adott esetben külső nyomásra vesz részt a terápián, kihat mind a biztonságérzet, mind a feldolgozás folyamatára. Bár sok esetben a társas környezet ösztönzően hathat, fontos, hogy a személy választási lehetősége ne sérüljön. Amennyiben ugyanis a külső hatás

Kaminer-Eagle (2010): i. m.

Judith Herman: Trauma and recovery: from domestic abuse to political terror, Pandora, London, 1992.

M. Friedman: Post-traumatic stress disorder: the latest assessment and treatment strategies, Compact Clinicals, Kansas City, 2003. 
erősebbnek bizonyul, a beavatkozás iránti elkötelezettség mértéke csökken, hátráltatva ezzel a feldolgozás folyamatát. ${ }^{38}$

Az ASR, ASD és PTSD kezelésére, - tekintettel a körülmények és tünetek közt megfigyelhető különbségekre -, más-más módszereket alkalmaznak. A harci stressz azonnali kezelése (ASR esetében) rövidebb, míg ennek ellentéteként a PTSD kezeléséhez már hosszú és mély terápiára van szükség. A stresszreakciók időbeli eltérése alapján tehát a kezelést is három csoportba sorolják. Az ASR esetében legtöbbször rövid, akut beavatkozás vagy az átélt traumáról folytatott azonnali beszélgetés jelenik meg, mint a traumatanácsadás módszere. Az időben néhány nappal hosszabb lefolyású ASD kezelésére rövid távú terápiás beavatkozásokat használnak, míg a PTSDben szenvedőknél a hosszú távú terápiás lehetőségek és a pszichoterápia bizonyult hatásosnak. ${ }^{39}$ Egyes megfigyelések tovább bontják a trauma fogalmát és az időbeli intervallum mellett megkülönböztetnek egyszerú és komplex változatokat. Az egyszerünek ítélt trauma kezelése gyakorlatilag megegyezik a fentiekben ismertetett időbeli dimenzióra épülő lehetőségekkel. A komplex trauma kezelése ezzel szemben speciális módszereket igényel. A kezelés módjának behatárolásához szükséges először a komplex jelző magyarázata. Komplex traumának nevezhetjük azokat az eseteket, amikor a (harci) stressz élményén felül a személy emberi méltóságának csorbítása, vagyis szándékos megszégyenítés történik. Ezekben az esetekben legalább 20 alkalmas kognitív viselkedésterápia (a továbbiakban: CBT) alkalmazása javasolt. ${ }^{40}$

\section{ASR kezelése}

Az akut beavatkozásokat sok esetben a „trauma debriefing” fogalmába sorolják. A trauma debriefing valójában egy komplex megközelítés, ami az átélt stresszeseményről való beszélgetés mellett tartalmazhat sürgősségi beavatkozást, pszichológiai elsősegélynyújtást, katonai beavatkozást és krízisintervenciót. ${ }^{41} \mathrm{~A}$ trauma debriefing alapjait tekintve megegyezik a Mitchell által az 1980-as években kidolgozott CISD (Critical Incident Stress Debriefing) módszerrel. A CISD eredeti célja a munkahelyi stressz kezelése volt, különös tekintettel az egészségügyi dolgozók és a tűzoltók

38 Az önkéntes részvétel bizonyos munkakörök esetében (például katonák vagy egyházi személyek) kérdéseket vethet fel. Bizonyos foglalkozások esetében ugyanis az egyéni döntéshozatal kihathat a személy közvetlen környezetén (katonák esetében például bajtársak) túl akár nagyobb csoportok (katonák esetében akár egész társadalmak; egyházi személyek esetében pedig a közösség(ek) tagjai) életére is. Az említett és ezekhez hasonló munkakörök esetében előfordulhat, hogy a pszichés problémák kezelése nem önkéntes alapú terápiás részvételen nyugszik. A kezelés felettes hatóság szempontjából bemutatott kihívásairól lásd: Ujházi Lóránd: Psychological Suitability in Relation to Holy Orders: Szent István Társulat, Budapest, 2007.; Ujházi Lóránd: A klerikusok pszichés alkalmassága és erre vonatkozóan az egyházi hatóság joga és kötelessége, Kánonjog: A Kánonjogi Posztgraduális Intézet Folyóirata, (2007/9) 101-121.; Ujházi Lóránd: A szent rend gyakorlásának és felvételének szabálytalanságai és akadályai: irregularitások és impedimentumok. Studia Wesprimiensia: Tanulmányok a Teológia és Szociális Munka Területéröl: A Veszprémi Érseki Hittudományi Főiskola Folyóirata, 10 (2008/1-2) 199-236.

39 Kaminer-Eagle (2010): i. m.

40 Emily A. Holmes - Nick Grey - Kerry A. D Young: Intrusive images and "hotspots" of trauma memories in Posttraumatic Stress Disorder: an exploratory investigation of emotions and cognitive themes, Journal of Behavior Therapy and Experimental Psychiatry, 36 (2005/1) 3-17.

41 Beverley Raphael - Matthew Dobson: Acute Posttraumatic Interventions, in: John Wilson - Matthew Friedman - Jacob Lindy (eds.), Treating Psychological Trauma and PTSD. The Guilford Press, New York, 2001, 139-158. 
csoportjára. A módszer a stresszesemény utáni 72 órán belül használható, csoportos foglalkozásként a traumát együtt átélt személyek részvételével. ${ }^{42} \mathrm{~A}$ CISD és a trauma debriefing közt azonban felfedezhető két jelentős eltérés. A CISD-t csoportos módszernek tervezték, míg a trauma debriefingnél több esetben az egyéni foglalkozást részesítik előnyben. Emellett Raphael és Dobson munkájában sem az ASR-t és ASD-t nem különíti el a kezelés módjait illetően, sem pedig konkrét időkeretet nem szab a módszer felhasználhatóságára. A szerzőpáros ugyanis úgy véli, hogy az akut beavatkozások mindaddig megfelelőek lehetnek, amíg a tünetegyüttes alapján egyértelműen meg nem állapítható a PTSD. Továbbá korábbi kutatásokban (lásd például Leibowitz és munkatársai 1999-es munkáját) azt találták, hogy az akut traumaintervenció hosszú távú pozitív hatása megkérdőjelezhető. ${ }^{43}$ Legtöbb esetben ugyanis számításba kell venni azt a tényt, hogy a beavatkozást követően a személyeknek vissza kell térnie ugyanazon munkakörülményekhez, mint amiben a traumát elszenvedték. A munkához való visszatérést pedig ez esetben a katonák úgy élhetik meg, mint egy külső erő nyomására történő, személyes szabadságukat és biztonságukat veszélyeztető eseményt. A szabad (saját, személyes) döntés hiánya pedig nagyfokú szorongáshoz és stresszhez vezethet, amellyel az intervenciós erőfeszítések hatása csökken, esetenként inverzzé válik. ${ }^{44}$

\section{ASD kezelése}

Az akut stresszreakciótól eltérően az ASD esetében a harci stressz rövid és középtávú hatásáról beszélhetünk. Az időbeli különbségekre tekintettel a trauma kezelésére az ASD-ben szenvedő személyeknél már nem elegendő a fentiekben ismertetett CISD vagy trauma debriefing módszerek használata. Helyettük a trauma mértéke és a tünetek fényében meghatározott számú terápiás ülések (általában 8-12 alkalom) alkalmazása javasolt. A személy preferenciáitól függően több modell áll a szakemberek rendelkezésére, amelyek az általános pszichoterápia paradigmáit veszik alapul. Mind az ASD, mind pedig a PTSD kezelésében gyakran használt módszerek a CBT, az EMDR (Eye Movement Desensitisation and Reprocessing), pszichodinamikus terápia vagy narratív terápia.

\section{CBT (Cognitive behaviour therapy)}

A kognitív viselkedésterápia (a továbbiakban: $\mathrm{CBT}$ ) alapja a tünetek megértése, vagyis annak a felismerése és elfogadása, hogy a stressz hatására kialakult viselkedéses válaszreakciók egy maladaptív tanulási, kondicionálási folyamat eredményei. A CBT tehát a korai klasszikus kondicionálás keretrendszerén alapul, feltételezve, hogy egy

42 Jeffrey T Mitchell: When disaster strikes... the critical incident stress debriefing process, Journal of Emergency Medical Services, 8 (1983/1) 36-39.

43 Stacey Leibowitz - Michaela Mendelsohn - Cathy Michelson: Child Rape: Extending the Therapeutic Intervention to Include the Mother-Child Dyad, South African Journal of Psychology, 29 (1999/3) 103-108.

44 Leibowitz-Mendelsohn-Michelson (1999): i. m. 
korábban semleges inger a trauma során szorongással teli színezetet kap. A terápiák során ennek az ingernek az átkeretezése történik. A kognitív viselkedésterápiák csoportjába többféle kezelési módszer tartozik, például: kognitív feldolgozó terápia $(\mathrm{CPT})^{45}$; stressz inokulációs képzés $(\mathrm{SIT})^{46}$; kognitív terápia $(\mathrm{CT})^{47}$. A példaként hozott kezelési formák jellemzően 9-16 ülést tartalmaznak. Több esetben a trauma hatékony feldolgozása érdekében kombinálják a módszereket. CBT esetén legalább három elvet tartanak szem előtt, vagyis minden esetben szükséges az átélt traumatikus események ismételt expozíciója - a szorongás csökkentése érdekében; stratégiák kidolgozása a szorongás kezelésére - például: relaxációs tréning segítségével; kognitív átkeretezés - a traumatikus élmény során kialakult maladaptív hiedelmek átértékelésére. ${ }^{48}$ Foa és munkatársai az alapelveket szem előtt tartva javasolják annak a terápiás ülésnek a felvételét, amin a trauma felidézése történik. A rögzített anyaggal ugyanis a kliens is megfigyelheti magát egy másik perspektívából és az ülések során pontosabban visszaidézhetők az emlékekre adott kezdeti reakciók is. ${ }^{49}$ A felvétel készítéséről, valamint egyéb - a felidézést segítő - segédeszközök alkalmazásáról a terápiában részt vevő személyt tájékoztatják. Tekintettel a módszer erős pszichoedukációs hatására, a CBT-t tartják a legsikeresebb eszköznek az ASD kezelésére. ${ }^{50}$

\section{Narratív terápia}

Igen erős érvek szólnak a CBT mellett, azonban több esetben a módszer alkalmazása korlátokba (például a CBT-re kiképzett szakemberek hiánya, kulturális különbségek, időbeli korlátok) ütközik. ${ }^{51}$ Ilyen esetekben más megközelítések módszereinek használata javasolt. Azokban a (főleg kollektivista) kultúrákban, ahol tradicionálisan a történetmesélés hagyománya beépült a mindennapi életbe, a narratív terápia kiválthatja a CBT-t. ${ }^{52}$ A narratív terápia középpontjában - hasonlóan a CBT-hez -, szintén az életesemények felidézése és átértékelése áll. Azonban a CBT-vel ellentétben a narratív terápia nem csak egy, a traumára adott maladaptív viselkedéses válaszként értelmezi az ASD-t. Ebben a megközelítésben ugyanis az átélt stresszeseményt felhasználják a személyiség fejlesztésére. A traumára építve erősítik a kliensben a reziliencia

45 P. Resick - M. Schnicke: Cognitive Processing Therapy for Sexual Assault Victims, Journal of Consulting and Clinical Psychology, 60 (1992/5) 748-756.

46 Don Meichenbaum: A Clinical Handbook/Practical Therapist Manual for Assessing and Treating Adults with PostTraumatic Stress Disorder (PTSD), Institute Press, Waterloo, Ontario, 1994.

47 A. Ehlers et al.: Cognitive Therapy for Post-Traumatic Stress Disorder: Development and Evaluation, Behaviour Research and Therapy, 43 (2005/4) 413-431.

48 Richard G. Tedeschi - Lawrence G Calhoun: Posttraumatic Growth: Conceptual Foundations and Empirical Evidence, Psychological Inquiry, 15 (2004/1) 1-18.

49 Edna Foa et al.: Treatment of posttraumatic stress disorder in rape victims: a comparison between cognitive-behavioural procedures and counselling, Journal of Consulting and Clinical Psychology, 59 (1991/5) 715-723.

50 Rothbaum et al.: Cognitive-Behavioral Therapy, in: Edna B. Foa, T. M. Keane - M. J. Friedman (eds.), Effective Treatments for PTSD: Practice Guidelines from the International Society for Traumatic Stress Studies, Guilford Press, New York, 2000, 60-83.

51 Kaminer-Eagle (2010): i. m.

52 Frank Neuner et al.: A Comparison of Narrative Exposure Therapy, Supportive Counselling and Psychoeducation for Treating Posttraumatic Stress Disorder in an African Refugee Settlement, Journal of Consulting and Clinical Psychology, $72(2004 / 4)$ 579-587. 
és a túlélésre való képesség meglétét, átkeretezve és erősségként a személyiségbe integrálva a terápia megkezdésekor negatív, szorongást keltő élményt. ${ }^{53} \mathrm{~A}$ terápiás ülések során a traumát fokozatosan eltávolítják a klienstől: ahelyett, hogy erősítenék az áldozat mivoltát, a túlélés motívumát hangsúlyozzák. Fontos kritérium továbbá, hogy a terapeuta-kliens kapcsolata együttmüködésre alapuljon. ${ }^{54}$

\section{Rövidtávú pszichodinamikus megközelítések}

Az ASD kezelésére a CBT és a narratív terápia mellett alkalmaznak rövidebb távú, pszichodinamikus terápiákat is. A BPP (Brief Psychodynamic Psychoterapy) 12-15 traumafókuszú ülésből áll. ${ }^{55} \mathrm{~A}$ módszer - hasonlóan a fentiekben ismertetettekhez - segítséget nyújt a trauma megértés útján történő feldolgozására. A terápiás folyamat leginkább kognitív, nem cél a karakter változása vagy az érzelmi katarzis. ${ }^{56}$ A BPP során a klienseket két típusba sorolják aszerint, hogy milyen a traumával szembeni védekező mechanizmusuk. Ez alapján a terapeuta törekszik arra, hogy a kliens számára legérthetőbb, leginkább feldolgozható módon kezdje meg a terápiás folyamatot. A folyamat fókuszában a trauma élménye áll, amelynek átdolgozása az élmény negatív töltetét addig tompítja, míg a személy által elfogadhatóvá válik. A munka során a traumatikus élményt kötik a múltbeli és jelenbeli tapasztalatokhoz, majd a terapeuta segítségével a kliens megismeri és értelmezi azokat a tudattalan tartalmakat, amelyek segítségével az emlékek közti egyensúly kialakulása megtörténhet. A pszichodinamikai megközelítések tehát az átélt események szubjektív értelmezésének eszközével dolgoznak. A kliens saját perspektívájából értelmezett és átértékelt eseményt kötik a korábbi tapasztalatokhoz, élményekhez. ${ }^{57} \mathrm{~A}$ módszer hátránya azonban, hogy a BPP hatékonyságával és használhatóságával kapcsolatban kevés kutatás született, így nem áll a szakemberek rendelkezésére a korábbi tapasztalatok rendszerezett és értékelt együttese. Akadnak olyan tanulmányok, amelyek fókuszában a pszichodinamikus terápiák hatása áll különböző traumát átélt személyek csoportját vizsgálva (például nemi erőszak áldozatai) vagy más módszerekkel (például hipnoterápia) összehasonlítva. A tanulmányok többsége azonban leginkább hosszabb távú terápiát leíró esetekre korlátozódik, így csak részben használható fel a BPP kapcsán.

\section{A PTSD kezelése}

Az ASR-hez és ASD-hez viszonyítva a poszttraumatikus stressz szindróma lefolyása a leghosszabb, így kezelése sem lehetséges rövid távú terápiákkal. A PTSD diagnosztizálása

53 Claire B Draucker: Narrative Therapy for Women Who Have Lived with Violence, Archives of Psychiatric Nursing, 12 (1998/3) 162-168.

54 Carrie Merscham,: Restorying trauma with narrative therapy: Using the phantom family, Family Journal, 8 (2000/3) 282-287.

55 Janice L. Krupnick: Brief Psychotherapy for Victims of Violent Crime, Victimology, 5 (1980/2-4) 347-354.

56 P. Peterson - M Prout - R. Schwarz: Posttraumatic Stress Disorder: a Clinician's Guide, Plenum Press, New York, 1991.

57 Kaminer-Eagle (2010): i. m. 
után az eset komplexitásától függően szükség lehet több hónapot, esetenként több évet felölelő terápiára. A pszichodinamikus megközelítés - bár létezik a fentiekben már ismertetett BPP változata - valójában hosszú távú kezelési lehetőségként hatékonyabb a trauma feldolgozásában. ${ }^{58}$

\section{Pszichodinamikus megközelítés}

A pszichodinamikus és pszichoanalitikus módszerek alkalmasak lehetnek a PTSD kezelésére. Bár különböző elméletek más és más perspektívából közelítik meg a traumatizáció és az ehhez kapcsolódó kezelések kérdését, a pszichodinamikus megközelítés képviselői kiemeltek néhány olyan kulcstényezőt, amelyek szerepe minden elméletben megkérdőjelezhetetlen. Ilyen például a szubjektivitás szerepe - vagyis a kezelés sikeréhez szükséges az eseményeket a kliens szürőjén keresztül vizsgálni és nem csupán objektívan értelmezni; az alkalmazkodás a kliens önvédő mechanizmusához - ugyanis a korábbi traumák feldolgozásának módja fogja meghatározni a PTSD feldolgozásának dinamikáját;,59 a kliens-terapeuta kapcsolata - amiről feltételezik, hogy tükrözi a korai tárgykapcsolatokat. ${ }^{60}$ Már a fő szempontokból is jól látszik, hogy a terápiás munkafolyamathoz időre van szükség. Fontos továbbá a folyamat korai szakaszában a jól működő terápiás kapcsolat kialakítása. A terapeuta feladata a tükrözés és a kliens segítése a trauma verbalizálásában. Ahhoz, hogy a terápia során elkerülhetők legyenek a kommunikációs eltérésekből adódó elcsúszások, már az első szakaszban szükséges kialakítani egy - mindkét fél számára hatékony kommunikációs - stratégiát. A kezdeti üléseken emellett a bizalom megteremtése zajlik, ami szintén elengedhetetlen a folyamat sikeréhez.

\section{MDT (Multi-dimensional treatment)}

Hosszú távú lehetőségként a fentiekben már bemutatott pszichodinamikus, pszichoanalitikus módszerek mellett a multidimenzionális kezelést alkalmazzák. Az MDT során komplex trauma kezelésére többféle módszert kombinálnak, mint például az egyéni terápia, páros tanácsadás vagy csoportterápia. Ilyenek például az Amerikai Egyesült Államok háborús veteránokat támogató, vagy több európai ország által létrehozott menekülteket segítő programjai. ${ }^{61}$ Tekintettel arra, hogy a módszer önmagában a fentiekben már bemutatott elemekre épül, ezek ismételt leírásától eltekintek. Fontos azonban megemlíteni, hogy a megközelítés már tartalmaz az egyénen túlmutató lehetőségeket is, vagyis felhasználja a társas támaszban rejlő pszichés erőforrásokat. A csoportos üléseken hasonló traumát átélt személyek vesznek részt, ami több előnnyel járhat. Több személy egyidejü kezelése egyrészt gazdaságosabb, másrészt a résztvevők

58 Caroline Garland (ed.): Understanding Trauma: a Psychoanalytical Approach, Duckworth, London, 1998.

59 Kaminer-Eagle (2010): i. m.

60 J. Watts - Gillian Eagle: When Objects Attack in Reality: Psychoanalytic Contributions to Formulations of the Impact and Treatment of Traumatic Stress Incidences: Part II, Psychoanalytic Psychotherapy in South Africa, (2002/2) 8-13.

61 Lásd például: www.torturecare.org.uk vagy https://irct.org/ 
megtapasztalják a csoport által nyújtott támogatás erejét. Továbbá a trauma feldolgozását nagymértékben segíti a tudat, hogy az egyén problémájával nincs egyedül, így csökken a megbélyegzés érzetének mértéke. Hátránya lehet azonban ezeknek a foglalkozásoknak, hogy a csoporttagok más-más szinten állnak a trauma feldolgozásában. ${ }^{62}$

\section{Összegzés}

A harci stressz vizsgálata komplex szemléletmódot igényel. A jelenség leírásához szükséges figyelembe venni a traumatikus élmény átélésének körülményeit, a tünetek megjelenésének idői vetületét és a személyes preferenciákat. Mind a módszerek, mind az egyén pszichés állapota tekintetében jelentős eltérésekről számol be a szakirodalom az azonnali és a késleltetett beavatkozások esetében. Míg az ASR és az ASD esetében rövidebb terápiák (lásd: trauma debriefing, CTB, narratív terápia) is megfelelőnek bizonyulnak a trauma feldolgozására, PTSD-ben szenvedőknél minden esetben hosszú, bizonyos esetekben akár évekig tartó kezelés szükséges. A terápiás folyamat hossza mellett fontos eltérés figyelhető meg az ülések gyakorisága, a folyamat mélysége és a felhasznált eszközök tekintetében is. Első lépésként tehát szükséges meghatározni a trauma átélésének időpontja és a tünetek megjelenése közt eltelt időt. Ennek alapján ugyanis besorolhatóvá válik a stresszreakció és felvázolhatók a kezelés lehetséges irányai, módszerei. Az idői vetület által behatárolt kezelési módok tovább szükíthetők a harci stresszt átélt személy preferenciái mentén. A személyes preferenciák ugyanis meghatározzák, hogy a felvázolt lehetőségek közül legnagyobb valószínüséggel melyek lesznek a leginkább használhatók a trauma feldolgozásában. Azoknál a személyeknél például, akik képesek könnyen verbalizálni élményeiket és érzelmeiket, olyan terápiás módszerek alkalmazása lehet célszerü, amelyek a beszédre építenek (például narratív terápia). Továbbá a kliens preferenciái mentén meghatározott terápiás mód hozzájárulhat a Herman-féle kritérium: a személyes biztonság érzetének megteremtése teljesüléséhez. Ezen felül a személyhez illesztett terápiás lehetőség kevesebb valószínűséggel vált ki negatív attitűdöt a kezelés irányába. Pozitív (vagy semleges) attitűd és az önkéntes részvétel ugyanis elengedhetetlenül szükséges a folyamat sikerességéhez. Az idői vetület és a személyes preferenciák vizsgálata mellett kulcsfontosságú továbbá feltárni a traumatikus élmény átélésének körülményeit. Kapcsolódóan Holmes és munkatársai traumafogalmához, a kezelés módjának kiválasztásához szükséges megkülönböztetni komplex és egyszerü formákat. Az egyszerű forma kezelése lényegében megegyezik az idői vetület mentén ismertetett ASR-ra, ASD-re és PTSD-re alkalmazott terápiás módszerekkel. Ezzel szemben a komplex forma kezelése kevésbé hangsúlyos elemnek tekinti a stresszesemény és stresszreakció közt eltelt időt. Azokban az esetekben ugyanis, mikor a személyes méltóság sérül, vagy szándékos megszégyenítésen esik át a kliens, mind időtartamban, mind pedig a felhasznált eszközök tekintetében a megszokott (egyszerü) esetektől eltérő terápiás módszerek alkalmazása javasolt.

62 Adeyinka M. Akinsulure-Smith: Brief Psychoeducational Group Work Treatment with Re-Traumatized Refugees and Asylum Seekers, Journal for Specialists in Group Work, 34 (2009/2) 137-150. 
A történelmi példák segítségével megfigyelhetők azok a főbb változások, amelyek mentén a harci stressz napjainkban ismert fogalma és kezelési módjai kialakultak. A hadviselés újabb és újabb formáinak megjelenésével párhuzamosan mélyült a harci stressz fogalmának és kezelési módjainak kutatása is. Az ismertetett példák tehát alátámasztják, hogy a harci stressz vizsgálata és kezelése nem lehetséges a jelenség komplexitásának megragadása nélkül. Szükséges figyelembe venni olyan alapvető aspektusokat (például idői vetület, személyes preferenciák, trauma típusa), amelyek mentén a trauma besorolhatóvá válik, segítve ezzel a feldolgozás és integrálás folyamatát. Mindezek mellett pedig szükséges az újabb tapasztalatok segítségével átértékelni és a hadviselés újabb kihívásaira reflektálva rugalmasan kezelni a jelenséget és hatásait.

\section{Felhasznált irodalom}

Akinsulure-Smith, Adeyinka M.: Brief Psychoeducational Group Work Treatment with Re-Traumatized Refugees and Asylum Seekers, Journal for Specialists in Group Work, 34 (2009/2) 137-150. DOI: https://doi.org/10.1080/01933920902798007

Artiss, Kenneth L.: Human Behaviour Under Stress: From Combat to Social Psychiatry, Military Medicine, 128 (1963/10) 1011-1015. DOI: https://doi.org/10.1093/milmed/128.10.1011

Babington, Anthony: Shell-Shock: A History of the Changing Attitudes to War Neurosis, Leo Cooper, London, 1997.

Barna Boglárka: A munkahelyi stressz idői vetülete és főbb forrásai a hadseregben, Hadtudományi Szemle, 11 (2018/1) 124-141.

Clausewitz, Carl von: A háborúról, Athenaeum, Budapest, 1917, http://mek.oszk. hu/13200/13240/pdf/13240_1.pdf (Letöltve: 2019. 01. 16.)

Doyle, Michael E. Major: Combat Stress Control Detachment: A Commander's Tool, Military Review, (2000/3) 65-71.

Draucker, Claire B.: Narrative therapy for women who have lived with violence, Archives of Psychiatric Nursing, 12 (1998/3) 162-168. DOI: https://doi.org/10.1016/ S0883-9417(98)80018-6

Ehlers, A. - Clark, D. - Hackmann, A. - McManus, F. - Fennel, M.: Cognitive therapy for post-traumatic stress disorder: development and evaluation, Behaviour Research and Therapy, 43 (2005/4) 413-431. DOI: https://doi.org/10.1016/j.brat.2004.03.006

Foa, Edna - Rothbaum, Barbara - Riggs, David - Murdock, Tamera: Treatment of posttraumatic stress disorder in rape victims: a comparison between cognitive-behavioural procedures and counselling, Journal of Consulting and Clinical Psychology, 59 (1991/5) 715-723. DOI: https://doi.org/10.1037//0022-006X.59.5.715

Friedman, M.: Post-traumatic stress disorder: the latest assessment and treatment strategies, Compact Clinicals, Kansas City, 2003.

Garland, Caroline (ed.): Understanding Trauma: A Psychoanalytical Approach, Duckworth, London, 1998.

Glenn, Russel W. - Helmus, Todd C.: A Look Back: A Brief History of Combat Psychiatry, in: Glenn, Russel W. - Helmus, Todd C. (eds.), Steeling the Mind, RAND Corporation, 2005, 9-22. 
Herman, Judith: Trauma and recovery: from domestic abuse to political terror, Pandora, London, 1992.

Holmes, Emily A. - Grey, Nick - Young, Kerry A. D.: Intrusive images and "hotspots" of trauma memories in Posttraumatic Stress Disorder: an exploratory investigation of emotions and cognitive themes, Journal of Behavior Therapy and Experimental Psychiatry, 36 (2005/1) 3-17. DOI: https://doi.org/10.1016/j.jbtep.2004.11.002 International Rehabilitation Council for Torture Victims, https://irct.org/

Jones, Edgar - Wessely, Simon: Psychiatric Battle Casualties: An Intra- and Interwar Comparison. British Journal of Psychiatry, 178 (2001/3) 242-247. DOI: https://doi. org/10.1192/bjp.178.3.242

Jones, Edgar - Hodgins-Vermaas, Robert - McCartney, Helen - Everitt, Brian - Beech, Charlotte - Poynter, Denise - Palmer, Ian - Hyams, Kenneth - Wessely, Simon: Post-Combat Syndromes from the Boer War to the Gulf War: A Cluster Analysis of Their Nature and Attribution, British Medical Journal, 324 (2002/7334) 397. DOI: www.doi.org/10.1136/bmj.324.7333.321

Jones, Franklin D.: Psychiatric Lessons of War, in: Jones, Franklin D. - Sparacino, L. R. - Wilcox, V. L. - Rothberg, J. M. - Stokes, J. W. (eds.), War Psychiatry, TMM Publications, Washington, D. C., 1995, 1-33.

Jones, Franklin D.: Traditional Warfare Combat Stress Casualties, in: Jones F. D. et al. (eds.), War Psychiatry, TMM Publications, Washington, D. C., 1995, 35-61.

Kaminer, Deborah - Eagle, Gillian: Trauma interventions for individuals, groups and communities, in: D. Kaminer, G. Eagle (eds.), Traumatic Stress in South Africa, Wits University Press, 2010. DOI: https://doi.org/10.26530/OAPEN_626383

Krupnick, Janice L.: Brief psychotherapy for victims of violent crime, Victimology, 5 (1980/2-4) 347-354.

Leibowitz, Stacey - Mendelsohn, Michaela - Michelson, Cathy: Child rape: extending the therapeutic intervention to include the mother-child dyad, South African Journal of Psychology, 29 (1999/3) 103-118. DOI: www.doi.org/10.1177/008124639902900301

Marlowe, David H.: Psychological and Psychosocial Consequences of Combat and Deployment with Special Emphasis on the Gulf War, RAND Corporation, Santa Monica, CA, 2001.

Matz, Adam K. - Wells, James B. - Minor, Kevin I. - Angel, Earl: Predictors of turnover intention among staff in juvenile correctional facilities: The relevance of job satisfaction and organizational commitment. Youth Violence and Juvenile Justice, 11 (2013/2) 115-131. DOI: https://doi.org/10.1177/1541204012460873

McCallum, Jack: Medicine, Military, in: Spencer C. Tucker (ed.), Encyclopedia of the Vietnam War: A Political, Social and Military History. ABC-CLIO, Santa Barbara, 1998, 423-428.

Meichenbaum, Don: A Clinical Handbook/Practical Therapist Manual for Assessing and Treating Adults with Post-traumatic Stress Disorder (PTSD), Institute Press, Waterloo, Ontario, 1994.

Merscham, Carrie: Restorying trauma with narrative therapy: using the phantom family, Family Journal, 8 (2000/3) 282-286. DOI: https://doi. org/10.1177/1066480700083013 
Mitchell, Jeffrey T.: When disaster strikes..., the critical incident stress debriefing process, Journal of Emergency Medical Services, 8 (1983/1) 36-39.

Neuner, Frank - Schauer, Margaret - Klaschik, Christine - Karunakara, Unni - Elbert, Thomas: A Comparison of Narrative Exposure Therapy, Supportive Counselling and Psychoeducation for Treating Posttraumatic Stress Disorder in an African Refugee Settlement, Journal of Consulting and Clinical Psychology, 72 (2004/4) 579-587. DOI: https://doi.org/10.1037/0022-006x.72.4.579

Noy, Shabtai - Levy, R. - Solomon, Zahava: Mental Health Care in the Lebanon War, 1982, Israel Journal of Medical Sciences, 20 (1984/4) 360-363.

Peterson, P. - Prout, M - Schwarz, R.: Posttraumatic Stress Disorder: A Clinician's Guide, Plenum Press, New York, 1991. DOI: https://doi.org/10.1007/978-1-4899-0756-1 Raphael, Beverley - Dobson, Matthew: Acute Posttraumatic Interventions, in: Wilson, John - Friedman, Matthew - Lindy, Jacob (eds.), Treating Psychological Trauma and PTSD, The Guilford Press, New York, 2001, 139-158.

Resick, Patricia - Schnicke, Monica: Cognitive Processing Therapy for Sexual Assault Victims, Journal of Consulting and Clinical Psychology, 60 (1992/5) 748-756. DOI: https://doi.org/10.1037//0022-006x.60.5.748

Barbara Rothbaum - Elizabeth Meadows - Patricia Resick - David W. Foy: CognitiveBehavioral Therapy, in: Edna B. Foa - Terence M. Keane - Matthew J. Friedman (eds.), Effective treatments for PTSD: Practice Guidelines from the International Society for Traumatic Stress Studies, Guilford Press, New York, 2000, 60-83.

Shephard, Ben: Shell-Shock on the Somme, RUSI Journal, 141 (1996/3) 51-56. DOI:https:// doi.org/10.1080/03071849608446033

Shephard, Ben: A War Of Nerves: Soldiers and Psychiatrists, 1914-1994. Pimlico, London, 2002.

Solomon, Zahava - Benbenishty, Rami: The Role of Proximity, Immediacy, and Expectancy in Frontline Treatment of Combat Stress Reaction Among Israelis in the Lebanon War, American Journal of Psychiatry, 143 (1986/5) 613-617. DOI: https://doi.org/10.1176/ajp.143.5.613

Szun-ce: A hadviselés törvényei, http://mek.oszk.hu/01300/01345/01345.htm (Letöltve: 2019. 02. 25.)

Tedeschi, Richard G. - Calhoun, Lawrence G.: Posttraumatic growth: conceptual foundations and empirical evidence, Psychological Inquiry, 15 (2004/1) 1-18. DOI: https://doi.org/10.1207/s15327965pli1501_01

Torturecare.org.uk, www.torturecare.org.uk

Ujházi Lóránd: A klerikusok pszichés alkalmassága és erre vonatkozóan az egyházi hatóság joga és kötelessége, Kánonjog: A Kánonjogi Posztgraduális Intézet Folyóirata, (2007/9) 101-121.

Ujházi Lóránd: Psychological Suitability in Relation to Holy Orders, Szent István Társulat, Budapest, 2007.

Ujházi Lóránd: A szent rend gyakorlásának és felvételének szabálytalanságai és akadályai: irregularitások és impedimentumok, Studia Wesprimiensia: Tanulmányok a Teológia és Szociális Munka Területeiröl: A Veszprémi Érseki Hittudományi Főiskola Folyóirata, 10 (2008/1-2) 199-236. 
Ullman, Sarah E. - Filipas, Henrietta H.: Predictors of PTSD symptom severity and social reactions in sexual assault victims, Journal of Traumatic Stress, 14 (2001/2) 369-389. DOI: https://doi.org/10.1023/A:1011125220522

Vegetius Renatus, Publius Flavius: Epitoma rei militaris. Várady László (ford.): A hadtudomány foglalata, in: Hahn István (szerk.), A hadművészet ókori klasszikusai, Zrínyi Katonai kiadó, Budapest, 1963, 751-865.

Völgyi Zoltán (2018) A harctevékenységekhez kapcsolódó stressz pszichológiai aspektusai, Hadtudományi Szemle, 11 (2018/1) 270-286.

Watts, J. - Eagle, Gillian: When objects attack in reality: psychoanalytic contributions to formulations of the impact and treatment of traumatic stress incidences: Part II., Psychoanalytic Psychotherapy in South Africa, 10 (2002/1) 1-24.

Xenophón: Kürosz nevelkedése/Anabázis, Bibliotheca Classica sorozat, Európa Könyvkiadó, Budapest, 1979.

Zrínyi Miklós: Vitéz hadnagy, (1650-1653), http://mek.oszk.hu/01100/01137/01137. htm\#11 (Letöltve: 2019. 02. 25.) 